\title{
Identification of virulence associated loci in the emerging broad host range plant pathogen Pseudomonas fuscovaginae
}

\author{
Hitendra Kumar Patel ${ }^{1}$, Maura Matiuzzo ${ }^{1}$, Iris Bertani ${ }^{1}$, Vincent de Paul Bigirimana ${ }^{1}$, Gavin J Ash ${ }^{3}$, \\ Monica Höfte ${ }^{2}$ and Vittorio Venturi ${ }^{*}$
}

\begin{abstract}
Background: Pseudomonas fuscovaginae (Pfv) is an emerging plant pathogen of rice and also of other gramineae plants. It causes sheath brown rot disease in rice with symptoms that are characterized by brown lesions on the flag leaf sheath, grain discoloration and sterility. It was first isolated as a high altitude pathogen in Japan and has since been reported in several countries throughout the world. Pfv is a broad host range pathogen and very little is known about its virulence mechanisms.

Results: An in planta screen of 1000 random independent Tn5 genomic mutants resulted in the isolation of nine mutants which showed altered virulence. Some of these isolates are mutated for functions which are known to be virulence associated factors in other phytopathogenic bacteria (eg. pil gene, phytotoxins and T6SS) and others might represent novel virulence loci.

Conclusions: Being an emerging pathogen worldwide, the broad host range pathogen $P f v$ has not yet been studied for its virulence functions. The roles of the nine loci identified in the in planta screen are discussed in relation to pathogenicity of Pfv. In summary, this article reports a first study on the virulence of this pathogen involving in planta screening studies and suggests the presence of several virulence features with known and novel functions in the Pseudomonas group of bacteria.
\end{abstract}

\section{Background}

Pseudomonas fuscovaginae (Pfv) is a Gram-negative, fluorescent pseudomonad and a member of Gamma proteobacteria [1,2]. Pfv is one of the 18 validly described Pseudomonas plant pathogenic species, which are part of the oxidase positive cluster $[3,4]$. This bacterium was first identified and reported as a pathogen of rice (Oryza sativa) in the temperate region of Japan in 1976 [2]. It has now been described in several other regions of the world where rice and other gramineae food crops are cultivated including Burundi [5], Madagascar [6], Mexico [7], the Philippines [8], Nepal [9], Brazil [10], China [11], Iran [12] and more recently in Malaysia [13] and Australia [14]. $P f v$ causes brown sheath rot disease in rice and also in other gramineae food crops including maize (Zea mays),

\footnotetext{
* Correspondence: venturi@icgeb.org

'International Centre for Genetic Engineering and Biotechnology, Trieste, Italy

Full list of author information is available at the end of the article
}

sorghum (Sorghum bicolour) and wheat (Triticum aestivum) [5,7]. Brown sheath rot symptoms on rice plants appear at all growing stages. At the seedling stage symptoms start with yellow to brown discoloration on the lower leaf sheath which later turns into grey-brown to dark-brown and ultimately, the infected seedlings rot and die. In mature rice plants $P f v$ symptoms can be observed on flag leaf sheaths, other leaf sheaths and also on the panicles. Under severe infection conditions, the entire leaf sheath becomes necrotic and dries out. Spikelets of emerging panicles may be discoloured, sterile or symptomless, except for small brown spots $[1,15]$.

A successful infection by a phytopathogenic bacterium is not a single step process and is coordinated by several functions including bacterial adherence, movement, colonization, invasion, and suppression of host immunity. Type IV pili are one of the best characterized adhesins in Pseudomonas pathogens and it has been shown to be involved in several functions including adhesion in 
P. syringae pv. phaseolicola [16], epiphytic fitness and survival in P. syringae pv. syringae [17] and P. syringae pv. tomato [18] and also in surface motility and virulence in P. syringae pv. tabaci $[19,20]$. The colonization process in Pseudomonas plant pathogens has been associated with exopolysaccharides (EPSs) shown to be involved in biofilm formation, epiphytic fitness and virulence [21,22]. The invasion process of plant pathogens has also been linked with secretion of several cell wall degrading enzymes including pectinolytic enzymes, cellulases and lipase through protein secretion systems [23]. Plant pathogenic bacteria also have strategies to suppress the host defense responses induced during the infection process by secretion of effector proteins directly into the host cell through a type III secretion system (T3SS) [24]. In addition to these functions, phytopathogenic pseudomonads produce several phytotoxins including coronatine, syringomycin, syringopeptin, phaseolotoxin, tabtoxin, and mangotoxin [25]. Quorum sensing (QS) signaling and its role in virulence has also been studied in several Pseudomonas species including $P$. aeruginosa [26-29], P. syringae pv. syringae [30] and P. fuscovaginae [31].

To our knowledge no genetic and molecular studies or screening for virulence-associated systems/functions in $P f v$ have been reported. Only a few biochemical studies have shown the production of three phytotoxins; namely syringotoxin, fuscopeptin A (FP-A) and fuscopeptin B (FP-B) [32,33] which have been shown to be able to generate the disease symptoms. We reported the role of the two QS systems in causing brown sheath rot by $P f v$ in rice [31] and have also determined the first draft genome sequence of a highly virulent $P f v$ strain [34]. In this study an in planta screening of 1000 genomic Tn5 mutants has provided some insight into the virulence associated functions in $P f v$.

\section{Results and discussion \\ Screening of $P$. fuscovaginae Tn5 mutants for altered virulence in planta}

As there are no major reports regarding virulence functions of this emerging phytopathogen, we performed an in planta screen of 1000 Tn5 genomic mutants to identify genes and/or pathways that might influence $P f v$ virulence potential. A Tn5 mutant bank of $P f v$ was generated as described in the Materials and Methods section and 1000 insertion mutants randomly selected and numbered from 1 to 1000 were tested for virulence on plants of Chenopodium quinoa. In this screen $C$. quinoa was chosen as a plant model over rice because the infection protocol for $P f v$ is simpler to perform in C. quinoa compared to rice and therefore more suitable for a high-throughput screen involving many mutants [31]. Plant inoculations were performed as described in the Materials and Methods section and virulence was assessed using the virulence score from
0 to 5 as previously described [31] and presented here in Additional file 1 . In the first round of screening we obtained 83 mutants that were altered for virulence compared to wild type. In order to verify the results, the 83 mutants were re-assessed for virulence in three biological replicates using two independent plants (total of six replicates). We then obtained a total of 9 mutants (Table 1) that displayed consistent and a significantly reduced virulence compared to wild type $P f v$ (Table 2). None of the mutants were affected in their growth pattern when grown in liquid rich media (data not shown).

In order to verify the virulence deficiency of identified mutants, infection assays were carried out using both $C$. quinoa and rice plants. It was of interest to test all the identified mutants in both models as the strain $P f v$ UPB0736 was first isolated as a rice pathogen. Rice infection was performed by syringe inoculation $(100 \mu \mathrm{l}$ of $10^{8} \mathrm{cfu} / \mathrm{ml}$ ) as described in the Materials and Methods section and virulence was assessed using the virulence score from 0 to 5 and also by measuring the lesion length (as presented in Additional file 2). In rice, 5 out of the 9 selected mutants had similar behaviour as in $C$. quinoa, being reduced in virulence when inoculated with a higher dose of bacteria $\left(100 \mu \mathrm{l}\right.$ of $\left.10^{8} \mathrm{cfu} / \mathrm{ml}\right)$. Three other mutants were also found with reduced virulence, although the virulence level was not significantly different compared to wild type. Surprisingly, $P f v 188$ on the other hand showed a similar level of virulence compared to wild type in rice (Figure 1).

We localized the Tn 5 insertion site in these selected nine Tn5 mutants and mapped their insertion position in the Pfv UPB0736 draft genome (Figure 2). The nine Tn5 mutants were localized in genes coding for the following features: an arsenic pump efflux ( $P f v$ 80), two hypothetical proteins ( $P f v$ 90; $P f v$ 188), the type IV pilus biogenesis protein, PilZ (Pfv 102), an N-acetyl-gamma-glutamylphosphate reductase ( $P f v 169)$, an acetylglutamate kinase (Pfv 270), a phage tail fiber homolog protein ( $P f v 420)$, a syringopeptin synthatase $C$ homolog (Pfv 445) and a bifunctional sulphate adenylyltransferase subunit 1 (Pfv 480) (Figure 2).

\section{Validation of the genetic screening by re-generation of knock-out mutants in the same loci and their genetic complementation}

In order to further verify the virulence phenotype of selected Tn 5 mutants, all mutants in the nine loci were independently re-generated via homologous recombination as described in the Materials and Methods section. In addition we also complemented three Tn5 mutants (Pfv 90, $P f v 420$ and $P f v 445$ ) by identifying the genomic region harbouring each of the three loci from a cosmid library. We re-assessed the virulence phenotype of the nine Tn5 mutants, their corresponding re-generated mutants and 3 
Table 1 Bacterial strains used in this study

\begin{tabular}{|c|c|c|}
\hline Strains & Relevant characteristics $^{a}$ & Reference/source \\
\hline \multicolumn{3}{|l|}{ E. coli. } \\
\hline $\mathrm{DH}_{5} \mathrm{a}$ & Cloning strain, $\mathrm{Nal}^{r}$ & {$[35]$} \\
\hline PRK2013 & Helper strain for tri-parental conjugation, $\mathrm{Km}^{\mathrm{r}}$ & [36] \\
\hline \multicolumn{3}{|l|}{ Pseudomonas fuscovaginae (Pfv) } \\
\hline PfV UPB0736 (NCPPB 3871) (WT) & Wild-type strain isolated from diseased rice in Madagascar; $\mathrm{Nf}^{r}, \mathrm{Amp}^{r}$ & {$[34]$} \\
\hline Pfv 80 & 80:: Tn5 of Pfv UPB0736; $\mathrm{Nf}^{r}, \mathrm{Km}^{\mathrm{r}}$ & This study \\
\hline Pfv 90 & 90:: Tn5 of Pfv UPB0736; $\mathrm{Nf}^{r}, \mathrm{Km}^{r}$ & This study \\
\hline Pfv 102 & 102:: Tn5 of Pfv UPB0736; Nf', Km ${ }^{r}$ & This study \\
\hline Pfv 169 & 169:: Tn5 of PfV UPB0736; Nf', Km & This study \\
\hline Pfv 188 & 188:: Tn5 of Pfv UPB0736; Nf', $\mathrm{Km}^{\mathrm{r}}$ & This study \\
\hline Pfv 270 & 270:: Tn5 of Pfv UPB0736; $\mathrm{Nf}^{\mathrm{r}}, \mathrm{Km}^{\mathrm{r}}$ & This study \\
\hline Pfv 420 & 420:: Tn5 of Pfv UPB0736; $\mathrm{Nf}^{r}, \mathrm{Km}^{\mathrm{r}}$ & This study \\
\hline Pfv 445 & 445:: Tn5 of Pfv UPB0736; Nf', Km & This study \\
\hline Pfv 480 & 480:: Tn5 of Pfv UPB0736; Nf', $\mathrm{Km}^{r}$ & This study \\
\hline Pfv 80-pKNOCK & 80:: pKNOCK mutant of Pfv UPB0736; $\mathrm{Nf}^{r}, \mathrm{Km}^{r}$ & This study \\
\hline PfV 90-pKNOCK & 90:: pKNOCK mutant of Pfv UPB0736; Nf', Km ${ }^{r}$ & This study \\
\hline Pfv 102-pKNOCK & 102:: pKNOCK mutant of PfV UPB0736; $\mathrm{Nf}^{r}, \mathrm{Km}^{\mathrm{r}}$ & This study \\
\hline Pfv 169-pKNOCK & 169:: pKNOCK mutant of Pfv UPB0736; Nf', Km ${ }^{r}$ & This study \\
\hline PfV 188-pKNOCK & 188:: pKNOCK mutant of PfV UPB0736; Nf', Km & This study \\
\hline Pfv 270-pKNOCK & 270:: pKNOCK mutant of PfV UPB0736; Nf', Km ${ }^{r}$ & This study \\
\hline Pfv 420-pKNOCK & 420:: pKNOCK mutant of Pfv UPB0736; $\mathrm{Nf}^{r}, \mathrm{Km}^{r}$ & This study \\
\hline Pfv 445-pKNOCK & 445:: pKNOCK mutant of Pfv UPB0736; Nf', Km ${ }^{r}$ & This study \\
\hline Pfv 480-pKNOCK & 480:: pKNOCK mutant of Pfv UPB0736; Nf', Km & This study \\
\hline Pfv $90+p \operatorname{Cos} 90$ & pCos90:: Pfv 90; $\mathrm{Nf}^{r}, \mathrm{Km}^{\mathrm{r}}, \mathrm{Tc}^{\mathrm{r}}$ & This study \\
\hline$P f v 420+p \operatorname{Cos} 420$ & $\mathrm{pCos} 420::$ Pfv 420; $\mathrm{Nf}^{r}, \mathrm{Km}^{\mathrm{r}}, \mathrm{Tc}^{\mathrm{r}}$ & This study \\
\hline Pfv $445+\mathrm{p} \operatorname{Cos} 445$ & $\mathrm{pCos} 445:: . P f v 445 ; \mathrm{Nf}^{r}, \mathrm{Km}^{r}, \mathrm{Tc}^{r}$ & This study \\
\hline
\end{tabular}

${ }^{a} ; \mathrm{Nal}^{r}, \mathrm{Nf}^{r} \mathrm{Km}^{r}, \mathrm{Tc}^{\mathrm{r}}$ and $\mathrm{Amp} \mathrm{p}^{\mathrm{r}}$ indicates nalidixic acid, nitrofurantoin, kanamycin, tetracycline and ampicillin respectively.

Table 2 Virulence screening of Tn5 transposon mutants of $P$. fuscovaginae in $C$. quinoa plants

\begin{tabular}{|c|c|c|}
\hline Pseudomonas fuscovaginae (Pfv) strains & Lesion scores in screen I (Average \pm S.D.) & Lesion scores in screen II (Average \pm S.D.) \\
\hline PfV UPB0736 (WT) & $5,5,5(5 \pm 0)$ & $5,5,5,5,5,5(5 \pm 0)$ \\
\hline Pfv 80 & $0,1,1(0.66 \pm 0.58)^{a}$ & $2,2,2,2,2,3(2.16 \pm 0.40)^{a}$ \\
\hline Pfv 90 & $1,1,1(1 \pm 0)^{\mathrm{a}}$ & $0,0,0,0,0,1(0.16 \pm 0.40)^{\mathrm{a}}$ \\
\hline PfV 102 & $0,0,0(0 \pm 0)^{a}$ & $0,1,1,2,2,3(1.50 \pm 1.05)^{\mathrm{a}}$ \\
\hline Pfv 169 & $0,0,0(0 \pm 0)^{a}$ & $0,0,0,0,0,0(0 \pm 0)^{a}$ \\
\hline Pfv 188 & $0,0,0(0 \pm 0)^{a}$ & $0,0,0,0,0,0(0 \pm 0)^{a}$ \\
\hline PfV 270 & $1,1,1(1 \pm 0)^{a}$ & $1,1,1,1,1,1(1 \pm 0)^{a}$ \\
\hline Pfv 420 & $2,2,3(2.33 \pm 0.58)^{a}$ & $2,2,3,3,3,3(2.66 \pm 0.52)^{a}$ \\
\hline Pfv 445 & $1,1,1(1 \pm 0)^{a}$ & $2,2,2,2,2,2(2 \pm 0)^{a}$ \\
\hline Pfv 480 & $1,1,1(1 \pm 0)^{a}$ & $1,1,1,1,1,1(1 \pm 0)^{a}$ \\
\hline
\end{tabular}



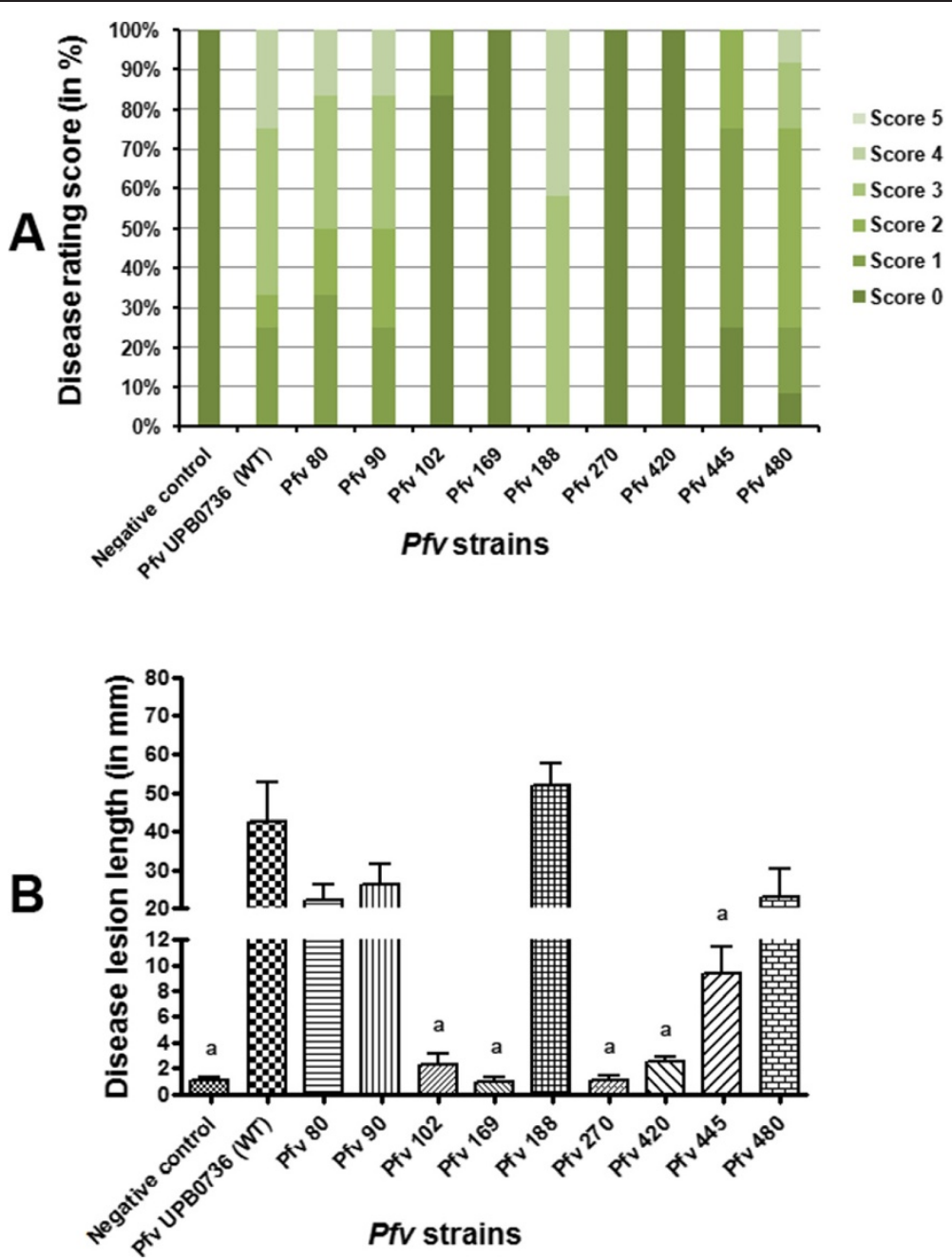

Figure 1 Virulence score of selected Tn5 mutants in rice. Five week old susceptible rice cultivar Co-39 plantlets were inoculated using a $1 \mathrm{ml}$ syringe with $100 \mu \mathrm{l}$ of the following Pfv strains: Pfv UPB0736 (WT), Pfv 80, Pfv 90, Pfv 102, Pfv 169, Pfv 188, Pfv 270, Pfv 420, Pfv 445 and Pfv 480. $0.15 \mathrm{M}$ saline solution was used as negative control. Data for rating score and lesion lengths were taken 8 days post inoculation. A. Disease severity based on rating score. Figure showing disease severity (in \%) for wild type and Tn 5 mutants of Pfv based on their rating score from 0 to 5 in rice plants. B. Disease severity based on lesion length. Figure showing disease severity (lesion length in $\mathrm{mm}$ ) for wild type and Tn5 mutants of Pfv based on their lesion length score. Error bars indicate the standard deviation for readings from at least 12 inoculated leaves. Similar results were obtained in independent experiments (data not shown). A two-tailed, paired ' $t$ ' test with $95 \%$ of confidence intervals for independent means was performed between the wild type and each of Tn5 mutants. a; significant difference to WT at $P<0.05$.

complemented strains in rice plants by pin prick inoculation (this type of infection results in the inoculation of a lower dose of bacteria as the sterile pin was dipped in a suspension of $10^{6} \mathrm{cfu} / \mathrm{ml}$ ). Eight of the nine Tn 5 mutants and their respective re-generated knock-outs showed similar results displaying virulence deficiency $(\mathrm{P}<0.05)$ as observed when inoculated with higher doses of bacteria in rice. Whereas Pfv 188 again displayed virulence symptoms similar to wild type strain as obtained with syringe inoculations (Figures 3 and 4). With respect to complementation in these experiments, the mutant $P f v$ 90, harbouring the cosmid clone carrying the corresponding wild-type locus, regained virulence completely. On the other hand the virulence assays with mutants $P f v 420$ and 445 harbouring cosmid clones isolated from the gene bank did not result in complementation (Figures 3 and 4). Mutant Pfv 445 had the Tn5 inserted in a gene homologous to the one coding for the syringopeptin $\mathrm{C}$ of $P$. syringae pv. syringae (Pss) B728a, thus this gene is most probably involved in the biosynthesis of one of the fuscopeptins produced by $P f v$. Peptide synthetases are very large ORFs; for example in Pss B728a the three syringopeptin genes sypA (16119 bp), sypB (16410 bp) and sypC (40614 bp) are at least $16 \mathrm{~kb}$ in size (Additional file 3). The Tn5 insertion region in mutant $P f v 445$ was found in a gene homologous to syringopeptin C of Pss B728a. This homologous gene in 


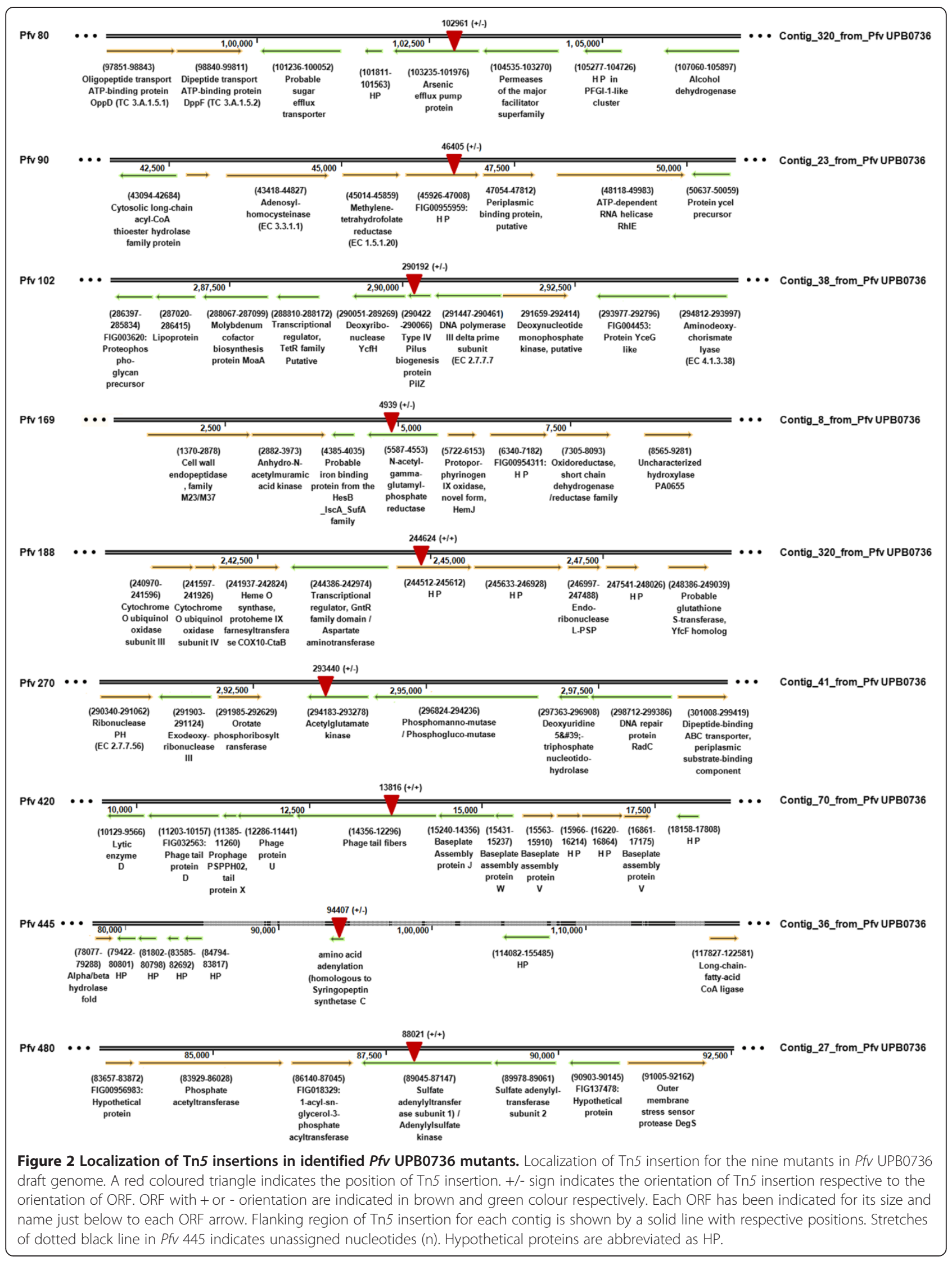


Figure 3 Virulence phenotype of selected Pfv strains in rice. Five week old susceptible rice cultivar Baldo were pin prick inoculated by dipping into $10^{6} \mathrm{cfu} / \mathrm{ml}$ inoculums of $P f v$ strains. A: Tn 5 mutants Pfv 80, Pfv 90, Pfv 102, Pfv 169, Pfv 188, Pfv 270, Pfv 420, Pfv 445 and PfV 480. B: knock-out mutants of PfV 80, PfV 90, PfV 102, PfV 169, PfV 188, Pfv 270, Pfv 420, Pfv 445 and Pfv 480. C: complemented strains Pfv $90+p \operatorname{Cos} 90$, Pfv $420+p \operatorname{Cos} 420$ and Pfv $445+$ pCos 445. Pfv UPB0736 (WT) and MQ water were used as positive and negative control respectively. Figure showing the disease symptoms were taken 10 days post inoculation.

the Pfv UPB0736 draft genome sequence contained stretches of unassigned nucleotides and it is likely to be an unusually large ORF. It is therefore possible that the cosmid clone used did not harbour the complete gene hence it could not complement the mutant $P f v$ 445. Mutant $P f v$ 420 had the Tn 5 transposon insertion in a gene encoding for a protein with significant homology to a phage tail fiber. In $P f v$ this gene is located in a cluster of genes with phage related functions that are probably part of an operon. Again, lack of complementation could be due to the cosmid clone not containing all the genetic material necessary for the complementation. Another possibility for not having complemented the virulence phenotype of $P f v$ 420 and Pfv 445 could be due to multicopy allele effects of these genes which may cause instability or fitness cost. In summary, 8/9 mutants identified using C. quinoa as infection model were also found affected for virulence in a similar manner in rice (except Pfv 188) when inoculated with low doses of bacteria. The same profile of virulence in rice was also obtained with independently generated mutants in the same loci as the identified virulence defective mutants; all these data further confirm the results of the genetic screen and indicate that the inactivated functions in the identified mutants are directly or indirectly associated with $P f v$ virulence.

\section{The nine genetic loci identified in the screen and their inference in virulence}

Here below we describe the nine loci in which the $\operatorname{Tn} 5$ insertions were located in relation to their potential role in virulence.

\section{Virulence deficient mutants Pfv 80, 169, 270 and 480 have transposon insertions in genes involved in various metabolic functions}

$P f v$ 80: the $\operatorname{Tn} 5$ was localized in a gene that displays significant identity to an arsenic efflux pump protein (Figure 2). Arsenic is a toxic metalloid and resistance to this metal has already been described in Gram-positive and also in Gram-negative bacteria [37]. We do not know the exact mechanism of involvement in virulence for arsenic pump efflux protein in $P f v$. However, being a toxic 

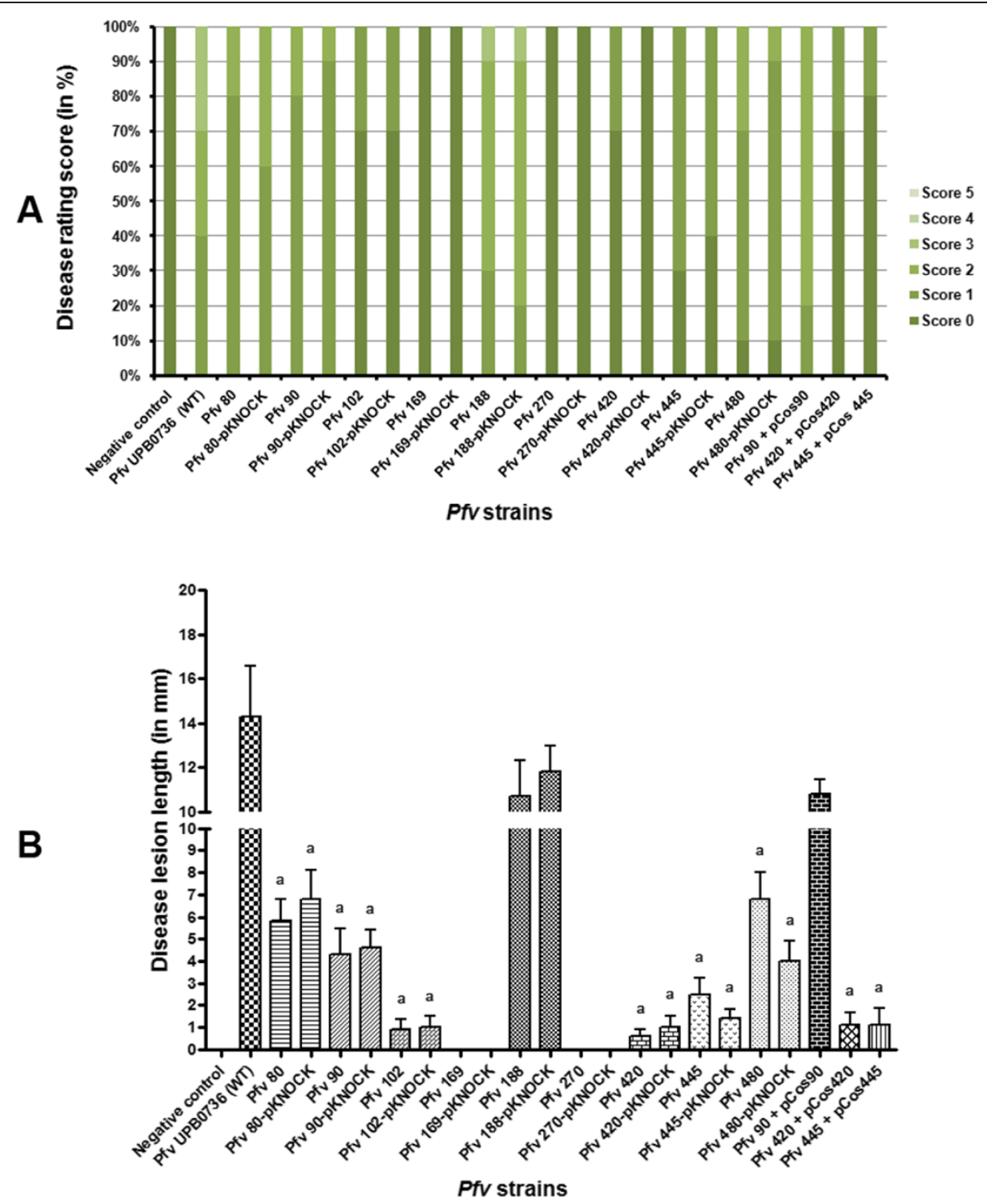

Figure 4 Virulence score of selected Pfv strains in rice. Five week old susceptible rice cultivar Baldo were pin prick inoculated by dipping into $10^{6} \mathrm{cfu} / \mathrm{ml}$ inoculums of following Pfv strains: Pfv UPB0736 (WT), nine Tn5 mutants, the respective nine knock-outs and three complemented strains. Sterile MQ water was used as negative control. Data for rating score and lesion lengths were taken 10 days post inoculation. A. Disease severity based on rating score. Figure showing disease severity (in \%) for Pfv strains based on their rating score from 0 to 5 in rice plants. B. Disease severity based on lesion length. Figure showing disease severity (lesion length in $\mathrm{mm}$ ) for Pfv strains based on their lesion length score. Error bars indicate the standard deviation for readings from at least 10 inoculated leaves. Similar results were obtained in independent experiments. A two-tailed, paired ' $t$ ' test with $95 \%$ of confidence intervals for independent means was performed between the wild type and each of Tn5 mutants. a; significant difference to WT at $P<0.05$.

metal, export of arsenic through this efflux protein could be essential for a proper metabolic function and survival of the bacterial cell. It is possible that the inability of the $P f v$ mutant bacterium to expel this or a related toxic metal ion from the cytoplasm diminishes its viability in planta and thus makes it less virulent or less fit for growth in this environment compared to the wild type $P f v$. Virulence studies in the grapevine pathogen, Xylella fastidiosa and in the fire blight pathogen, Erwinia amylovora,
tolC mutant affected for efflux pump functions have shown their involvement in virulence and in planta fitness $[38,39]$. It is possible that these efflux pumps are involved in exporting heavy metals, antimicrobials or harmful plant phenolic compounds which are released as part of the plant defense response.

$P f v 169$ and $P f v$ 270: In both mutants $P f v 169$ and $P f v$ 270 , the Tn5 was located in genes involved in the biosynthesis of the amino acid arginine [38]. Pfv 169 and 
Pfv 270 were found mutated in an $\mathrm{N}$-acetyl- $\gamma$-glutamylphosphate reductase gene $(\arg C)$ and $\mathrm{N}$-acetylglutamate kinase gene $(\arg B)$ respectively. The two enzymes catalyze the conversion of $\mathrm{N}$-acetylglutamate in $\mathrm{N}$-acetylglutamate semialdehyde, via $\mathrm{N}$-acetylglutamyl phosphate. Specifically, $\mathrm{N}$-acetylglutamate kinase encodes the key enzyme for the biosynthesis of arginine and is inhibited by the reaction product $[39,40]$. In order to further verify that the two isolated mutants were affected for arginine biosynthesis, an arginine auxotrophy assay was performed as described in the Materials and Methods section. Pfv 169 and Pfv 270 mutants and their respective re-generated mutants were found affected for growth on M9 agar plates lacking the amino acid arginine. Supplementation of arginine in M9 agar restored the growth defect of $P f v 169$ and $P f v$ 270 mutants and their respective re-generated mutants (Additional file 4). The chemical complementation by arginine supplementation further confirmed that the two mutants affect the biosynthesis are involved in arginine biosynthesis pathway. Besides having a crucial role in metabolism and growth, arginine was also shown to have a role in virulence. Arginine is one of the components of ethylene biosynthesis and together with oxoglutarate, is used by the ethylene forming enzyme (EFE) to produce ethylene. Mutants in efe no longer produce ethylene and were found virulence deficient in P. syringae pvs. glycinea and phaseolicola [41]. Interestingly, a homolog of efe is present in Pfv UPB0736 draft genome (data not shown). Arginine is also a fundamental part of the signal peptide that directs the protein to the transport system called twin-arginine translocation system. The consensus sequence of the proteins harbouring the double arginine motif, contains two arginine repeated Ser/Thr-Arg-Arg-X-Phe-Leu-Lys. Furthermore, mutants for the twin-arginine translocation system in P. syringae spp. showed reduced viability and virulence in planta $[42,43]$. It is therefore possible that the reduced virulence of mutants $P f v 169$ and 270 is caused not only by a deficiency in the metabolism of arginine but also due to a role directly related to pathogenesis via ethylene and protein transport.

Pfv 480: Mutant Pfv 480 had a mutation in a gene that encodes a bi-functional protein with two enzymatic activities: sulfate adenylyltransferase and adenylylsulfate kinase. Both of these activities are important in the metabolism of sulfur. The sulfate adenylyltransferase catalyzes the first intracellular reaction for the assimilation of sulfur with the use of a molecule of ATP and leading to the formation of adenosine-5-phosphosulfate (APS). This compound is pivotal for the biosynthesis pathway of amino acids that contain sulfur, namely cysteine and methionine. The adenylylsulfate kinase utilized the same substrate as APS catalyzing its conversion into 3'-phosphoadenosine 5'-phosphosulfate (PAPS) using ATP molecules. PAPS is a universal donor of the sulfate group and is used as the substrate for important enzymes such as sulfotransferase [44]. It is currently unknown how these enzymes crucial for the metabolism of sulfur are involved in virulence.

\section{Virulence deficient mutant Pfv 102 is affected in type IV pili biosynthesis}

The Tn5 transposon localized in the Pfv 102 mutant was found in Type IV pilus biogenesis gene pilZ encoding a protein that displayed significant identity (82 to 92\%) with PilZ of other pseudomonads. The PilZ protein is one of the several Pil proteins that are associated with type IV pili biosynthesis. PilZ is the only protein that is not part of the pili biosynthesis operon and is located as a single transcriptional unit in the genome of pseudomonads. Type IV pili genes are found not only in pseudomonads but also in other Gram-negative bacteria including xanthomonads and are implicated in a wide spectrum of roles including adhesion, motility, secretion and virulence. The role of PilZ in the formation of Type IV pili has not yet been well established. In some cases, knock-out mutants are incapable of secreting a protein which constitutes the pilus whereas in other cases PilZ does not seem to be essential for the formation of the pilus and for bacterial movement [45-47]. In recent years, sequencing of several bacterial genomes has revealed the presence of a PilZ domain in many proteins and has associated the function of this domain with the binding of the second-messenger cyclic guanosine monophosphate [46]. The c-di-GMP regulates many functions including aggregation, biofilm formation, EPS production, adhesion, movement and virulence [48]. It is possible that PilZ in $P f v$ can influence the signalling cascade mediated by c-di-GMP that could be involved in the pathogenic process.

\section{Virulence deficient mutant Pfv 420 is most likely affected in type VI secretion machinery}

Tn5 transposon localized in Pfv 420 mutant was found in a gene encoding a protein annotated as a phage tail fiber in $P f v$ UPB0736. This gene was found adjacent to other loci encoding phage related proteins; namely the phage protein $U$ and baseplate assembly protein J (Figure 2). Phage related functions are reported to be present in $25 \%$ of the Gram-negative bacterial genomes [49]. These genes encode for protein components that are structurally similar to tailed bacteriophages and are possibly involved in synthesizing a specialized contractile injection system that is known as Type VI secretion system (T6SS). Based on structural similarities, T6SS appeared as an inverted phage tail on the surface of the bacterial cell and it secretes effector proteins into the extracellular milieu or injects them directly into host cells by a puncturing mechanism [50-53]. A common evolutionary history has been 
proposed for the two injection machines present in bacteria and bacteriophages [52,54]. In plant associated bacteria, T6SS has been implicated in several functions including tumorigenesis in Agrobacterium [55], programmed cell death in the filamentous fungus Neurospora crassa by Pss B728a [56] and virulence in Pectobacterium [57]. Interestingly, P. fuscovaginae UPB0736 possesses a T6SS (data not shown). Consequently the Tn5 mutation in phage tail fiber-like protein most likely results in a non-functional T6SS secretion machinery for delivery of effector proteins in Pfv UPB0736 thus affecting virulence.

\section{Virulence deficient mutant Pfv 445 is most likely affected in phytotoxin production}

In this mutant the sequence of the gene inactivated by Tn 5 displays $96 \%$ identity with the gene of $P$. syringae that encodes an enzyme called syringopeptin synthetase $\mathrm{C}(\operatorname{syp} C)$. In $P$. syringae this gene is 40614 bp long and is part of a gene cluster of $73800 \mathrm{bp}$ that also includes syringopeptin synthetase A $(\operatorname{syp} A)$ and syringopeptin synthetase B $(\operatorname{syp} B)$ [58] (Additional file 3$)$. The genetic organization of these loci reveals that several genes flanking this locus are conserved among other Pseudomonas cyclic lipopeptides (CLP) biosynthesis clusters, including two genes encoding a putative macrolide transporter MacA and MacB. Genes encoding MacA and $\mathrm{MacB}$ have been reported in syringopeptin, syringomycin $[59,60]$ and entolycin biosynthesis gene clusters [61] and they were also found in Pfv UPB0736 (data not shown). The three peptide synthetases are responsible for the biosynthesis of non-ribosomal syringopeptin, which represents one of the major virulence factors in $P$. syringae [62]. Pfv produces phytotoxins which are similar to syringopeptin and are called fuscopeptins A and B [63]. These lipodepsipeptides show numerous structural and functional characteristics common to syringopeptin isolated from $P$. syringae. The distinguishing feature of the mechanism of action of these lipodepsipeptides is their ability to interact with biological membranes. The amphipathic nature of these molecules allows their insertion into the lipid bilayer, with the consequent formation of ion channels that cause the alteration of the membrane potential and in turn the loss of intracellular material [64]. The leakage from the host cells enriches the intercellular fluid with sucrose, amino acids, inorganic ions and other supplements that could be supporting the bacterial multiplication [63]. These phytotoxins are also able to play a role on disease symptoms by inducing injuries in the host plant. Syringotoxin has also properties of surfactant, fungicidal action and alteration in proton gradient. The antagonistic activity is likely to increase the competitive ability of $P f v$ against other colonizers of leaf surfaces. Although in earlier studies three $P f v$ phytotoxins were characterized biochemically, here we report that a mutant in a vital gene for the biosynthesis of at least one of them results in $P f v$ being significantly less virulent.

\section{Virulence deficient mutant affected in hypothetical proteins (Pfv 90 and Pfv 188)}

Pfv 90 mutant had a Tn5 insertion localised in a gene encoding for a hypothetical protein; adjacent to this ORF there is a methylene tetrahydrofolate reductase gene and a gene encoding a periplasmic binding protein (Figure 2). The spacing between the gene encoding the hypothetical protein and the next ORF (periplasmic binding protein) is only $46 \mathrm{bp}$ thus we cannot exclude that the Pfv 90 mutant phenotype that could be associated with periplasmic binding gene located downstream in an operonic organization. Mutant $P f v 188$ on the other hand, had the Tn5 insertion localized in a gene coding for a hypothetical protein that is flanked by a gene coding for a transcriptional regulator possessing a GntR family domain on one side and by a gene encoding a hypothetical protein on the other side. The gene encoding the neighbouring hypothetical protein is $21 \mathrm{bp}$ away from the gene in which Tn 5 insertion is localised hence they could be organized in operonic structure. Complementation using cosmid clones resulted in the restoration of virulence for $P f v 90$ indicating that $P f v 90$ locus was responsible for causing a virulence deficiency. We did not find any information related to virulence functions for $P f v 90$ in the literature suggesting that this is a novel gene and is implicated in virulence in $P f v$.

\section{Conclusions}

Despite the importance of $P f v$ as an emerging pathogen worldwide, to date no major studies have been performed to understand the mechanisms of $P f v$ pathogenicity. In 2012 we reported the first genome sequence of a highly virulent strain UPB0736 [34] and since then the genome sequence of another strain has been published [65] and many more genomes will most probably be sequenced in the future. In this study, we sought to identify and characterize some of the genes involved in $P f v$ virulence through an in planta screening of 1000 Tn5 mutants; nine mutants that showed virulence deficiency compared to the wild type were identified. The inactivated loci in these mutants include some metabolic functions and also some known virulence associated functions such as type IV pilus biogenesis protein PilZ, T6SS machinery and syringopeptin synthetase. The results of this study highlight the fact that $P f v$ might share features of some of its virulence mechanisms with other phytopathogens. In addition, new loci never reported as being involved in virulence and encoding for hypothetical proteins have been found. Genome mining with future virulence studies will further 
highlight the mechanisms of virulence of this broad host range emerging phytopathogen.

\section{Methods}

\section{Bacterial strains, plasmids, and culture media}

The bacterial strains used in this work are listed in Table 1. The plasmids used and generated in this study are listed in Additional file 5. Pseudomonas fuscovaginae (Pfv) strains were grown at $28^{\circ} \mathrm{C}$ in Luria Bertani (LB)/ King's B (KB) medium, and $E$. coli strains were grown at $37^{\circ} \mathrm{C}$ in LB medium, as described previously [31]. The concentrations of antibiotics used in this study were as follows: Nitrofurantoin (Nf); 100-150 $\mu \mathrm{g} / \mathrm{ml}$, Ampicillin (Amp); $100 \mu \mathrm{g} / \mathrm{ml}$, Kanamycin (Km); $50 \mu \mathrm{g} / \mathrm{ml}$, Tetracyclin (Tc) $30 \mu \mathrm{g} / \mathrm{ml}$ for Pfv and Amp; $75 \mu \mathrm{g} / \mathrm{ml}, \mathrm{Km} ; 50 \mu \mathrm{g} / \mathrm{ml}$, Tc; $15 \mu \mathrm{g} / \mathrm{ml}$ for $E$. coli.

\section{Recombinant DNA techniques}

Routine DNA manipulation steps such as digestion with restriction enzymes, agarose gel electrophoresis, purification of DNA fragments, ligations with T4 ligase, radioactive labelling by random priming and transformation of E. coli etc. were performed as described previously [66]. Colony hybridizations were performed using $\mathrm{N}+$ Hybond membrane (Amersham Biosciences); plasmids were purified using the EuroGold plasmid columns (Euro Clone) or with the alkaline lysis method [67]; total DNA from Pfv strains were isolated by Sarkosyl/Pronase lysis as described previously [68]. PCR amplifications were performed using Go-Taq DNA polymerase or pfu DNA polymerase (Promega). The oligonucleotide primers used in this study are listed in Additional file 6. Automated sequencing was performed by Macrogen sequence service (Europe). Triparental matings between $E$. coli and $P f v$ were carried out with the helper strain E. coli DH5 $\alpha$ (pRK2013) [36].

\section{Generation of Tn5 mutant library of Pfv UPB0736}

Tn5 mutagenesis was performed by using triparental matings between donor E. coli (pSUP2021) containing the transposon $\operatorname{Tn} 5$ (Km resistance), a helper E. coli strain (pRK2013) and recipient Pfv UPB0736 strain. Briefly, Pfv UPB0736, donor and helper E. coli strains were grown overnight in $20 \mathrm{ml}$ of LB media supplemented with appropriate antibiotics. Cells were pelleted, washed and re-suspended in $10 \mathrm{ml}$ of sterile LB media. Absorbance of all three strains were measured and cells were mixed in the following ratio: recipient $P f v$ UPB0736, $2 \times 10^{8}$ colony forming units (cfu/ml); helper E. coli, $4 \times 10^{9}$ $\mathrm{cfu} / \mathrm{ml}$; donor $E$. coli, $4 \times 10^{9} \mathrm{cfu} / \mathrm{ml}$. The mixture of cells were pelleted out, re-suspended in small volume of LB media and spotted onto Hybond N Plus nylon membrane (Amersham Pharmacia Biotech) that was overlaid on LB agar. Overnight incubated cells grown at $28^{\circ} \mathrm{C}$ were scraped from the membrane and re-suspended in $1 \mathrm{~mL}$ of sterile LB media. The cell suspension $(50 \mu \mathrm{l}$ each) was plated on LB agar plates containing $\mathrm{Nf}$ and $\mathrm{Km}$. The plates were incubated at $28^{\circ} \mathrm{C}$ for $2-3$ days to allow the growth of transconjugants ( $\operatorname{Tn} 5$ mutants). The $P f v$ Tn5 mutants were then patched onto LB agar plates with $\mathrm{Nf}$ and $\mathrm{Km}$, grown in liquid media and a glycerol stock was prepared and stored at $-80^{\circ} \mathrm{C}$.

\section{Screening of Pfv UPB0736 Tn5 mutants for virulence deficiency in Chenopodium quinoa (C. quinoa) and rice plants}

One thousand independent Tn5 mutants of Pfv UPB0736 were grown on fresh LB agar plates and inoculated individually in greenhouse-grown 2 week old C. quinoa plants. Inoculation was performed using a needle (size; $21 \mathrm{G} \times 1 \frac{1 / 2}{2}$ ) by touching the strains on plates and pricking onto twigs of C. quinoa plants. After 5 days of inoculations, brown sheath rot disease symptoms were observed and scored on a scale of 0 to 5 as previously reported [31] and shown again here in Additional file 1. Pfv Tn5 mutants with deficiency in virulence compared to wild type were subjected to a second round of screening using two independent plants.

In order to verify the virulence phenotype of selected Tn5 mutants from the C. quinoa screen, mutants were re-inoculated on rice plants which is a real host for this bacterium. Rice plants (cultivar Co-39) were grown in the growth chamber at $28 \pm 4^{\circ} \mathrm{C}$ and approximately $70 \%$ relative humidity. Along with wild type Pfv UPB0736, the selected $\operatorname{Tn} 5$ mutants were grown for $48 \mathrm{hrs}$ in $\mathrm{KB}$ medium. Bacterial cultures were diluted to $10^{8} \mathrm{cfu} / \mathrm{ml}$ using $0.15 \mathrm{M}$ saline solution and inoculated onto five week-old rice plants using a $1 \mathrm{ml}$ syringe. Inoculation was performed by injecting $100 \mu \mathrm{l}$ of bacterial culture in the rice plantlet at $5 \mathrm{~cm}$ above ground. After inoculation, plantlets were kept in a humid chamber at $20-30^{\circ} \mathrm{C}$ for disease development. Each bacterial strain was inoculated in rice plantlets in at least 12 replicates. Eight days after inoculation, data for disease severity in lesion lengths $(\mathrm{mm})$ and disease rating score (on a scale from 0 to 5) were collected and analysed for statistical significance using two-tailed, paired ' $t$ ' test with $95 \%$ of confidence intervals.

\section{Localization of $\operatorname{Tn} 5$ insertion}

Genomic DNA was isolated from selected Pfv Tn5 mutants and double digested either with BamHI + EcoRI, BamHI + SacI or BamHI + ClaI. These double digested products were ligated in pBluescript (double digested with the corresponding set of enzymes), transformed into DH5a E. coli cells and selected on LB agar plates with ampicillin $(75 \mu \mathrm{g} / \mathrm{ml})+$ kanamycin $(50 \mu \mathrm{g} / \mathrm{ml})$. These pBluescript clones having the insertion of Tn5 flanking regions were sequenced using Tn5 specific Tn5-Ext primers 
(Additional file 6). Sequences obtained were subjected to homology searches using NCBI Blast and also with the draft genome sequence of Pfv UPB0736 using a local blast algorithm. The exact positions of $\mathrm{Tn} 5$ insertion were mapped in the Pfv UPB0736 draft genome. We also performed arbitrary PCR using pairs of primers mentioned in Additional file 6 as previously described [69]. Arbitrary PCR products cloned in pGEM-T easy were also sequenced using pGEM-T easy vector specific primers.

\section{Confirmation of Tn5 mutations}

The selected $\operatorname{Tn} 5$ mutants were reconstructed by deletion of the wild-type genes via homologous recombination with the use of the pKNOCK-Km suicide delivery system. Briefly, an internal fragment of each Tn5 insertion locus was amplified by PCR using primers listed in Additional file 6 and cloned in pGEMT-easy vector. EcoRI digested internal fragments were ligated to EcoRI digested pKNOCK-Km and transformed into $\mathrm{C} 118$ cells yielding pKNOCK plasmids having internal fragments from selected Tn5 loci. These pKNOCK plasmids were further used as a suicide delivery system and the nine Tn $5 \mathrm{mu}-$ tants from $P f v 80$ to $P f v 480$ mutants were regenerated in the wild-type as previously described [70]. Pfv mutant strains were verified by PCR analysis and sequencing.

In order to complement Pfv UPB0736 Tn5 mutants, a cosmid library was constructed from the Pfv UPB0736 strain by using the cosmid pLAFR3 [71] as a vector. Insert DNA was prepared by partial EcoRI digestion of the genomic DNA and then ligated into the corresponding site in pLAFR3. The ligated DNA was then packaged into $\lambda$ phage heads using Gigapack III Gold packaging extract (Stratagene) and the phage particles were transduced to E. coli HB101 as recommended by the supplier. In order to identify the cosmids containing the genes of interest (90, 420 and 445), the cosmid library was screened using radio-labelled probes for Tn5 insert regions from 90, 420 and 445 in colony hybridization. We obtained respective cosmid clones pCos 90, pCos 420 and pCos 445 in this screen. It is not known whether the cosmids contain the full length genes for 90, 420 and 445 (Additional file 5) and they were introduced in Pfv 90, Pfv 420 and $P f v 445$ Tn5 mutants respectively by conjugation. Positive complemented clones were selected on LBA plates supplemented with Nf, Km and Tc.

\section{Arginine auxotrophy assay}

Stock solution of arginine-HCl (Sigma Chemicals) was prepared at a concentration of $100 \mathrm{mg} / \mathrm{ml}$ in sterile MQ water and filter sterilized. M9 agar plates with $0.2 \%$ glucose and with and without arginine $(100 \mu \mathrm{g} / \mathrm{ml})$ were prepared. The $P f v$ wild type strain, the two arginine biosynthesis defective Tn5 mutants $P f v 169$ and $P f v$ 270 , their respective re-created knock-out mutants and one other Tn5 mutant $P f v 102$ as a control were streaked onto each of these plates and incubated at $30^{\circ} \mathrm{C}$ for 24-48 hrs.

\section{Virulence assay in rice by pin prick inoculation}

Pfv in planta virulence assay was performed on rice plants by pin pricking method with some modifications as described previously [31]. Briefly, the seeds of a susceptible rice variety (Baldo) were surface sterilized using washes with hypochloride and sterile MQ water. Surface sterilized rice seeds were germinated on a sterile filter paper in a petriplate in the dark at $30^{\circ} \mathrm{C}$. Rice seedlings of 5 to $6 \mathrm{~cm}$ growth stages were planted in $50 \mathrm{ml}$ falcon tubes containing Hoaglands solutions with $0.5 \%$ agar. The transplanted rice plants were maintained in a climate controlled room with conditions set to $70 \%$ humidity, $16 / 8$ hours light/dark and temperature at $28^{\circ} \mathrm{C}$ and watered regularly. For inoculation, $P f v$ strains were grown for $24 \mathrm{hrs}$ on LBA medium supplemented with appropriate antibiotics, at $30^{\circ} \mathrm{C}$. Bacterial cultures were pelleted down washed with sterile MQ water and adjusted to approximately $10^{6} \mathrm{cfu} / \mathrm{ml}$ in sterile MQ water. Four to five week old rice plants were pin prick inoculated using a sterile board pin by dipping in the bacterial inoculum. For each strain, 10 plants were inoculated in two different sites each and control plants were inoculated in the similar manner using sterile MQ water. In order to determine in planta virulence of $P f v$ strains, disease severity was assessed on the $10^{\text {th }}$ day post inoculation by measuring the browning lesion length neighboring to the zone of inoculation and also by assessing their disease rating score (scale of 0 to 5). Virulence score with average and standard deviations are presented. The statistical significance was performed using two-tailed, paired ' $t$ ' test with $95 \%$ of confidence intervals.

\section{Additional files}

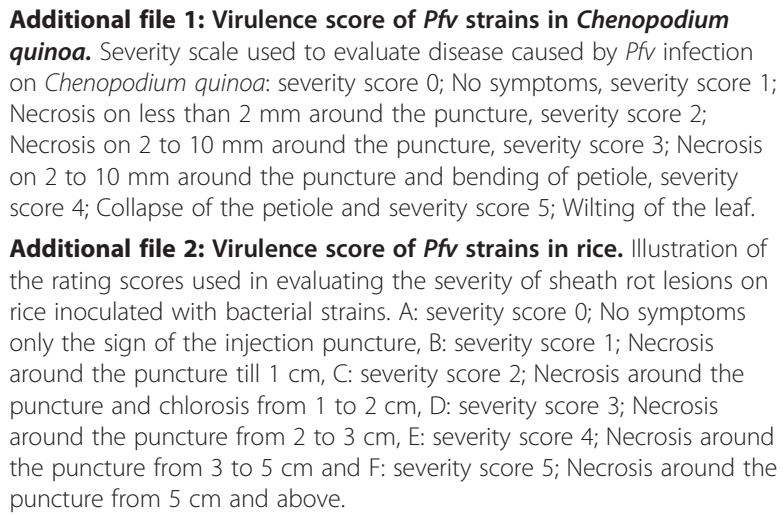

Additional file 2: Virulence score of Pfv strains in rice. Illustration of the rating scores used in evaluating the severity of sheath rot lesions on rice inoculated with bacterial strains. A: severity score 0; No symptoms only the sign of the injection puncture, B: severity score 1; Necrosis around the puncture till $1 \mathrm{~cm}, \mathrm{C}$ : severity score 2; Necrosis around the puncture and chlorosis from 1 to $2 \mathrm{~cm}$, D: severity score 3; Necrosis around the puncture from 2 to $3 \mathrm{~cm}$, E: severity score 4; Necrosis around the puncture from 3 to $5 \mathrm{~cm}$ and F: severity score 5; Necrosis around the puncture from $5 \mathrm{~cm}$ and above.

Additional file 3: Syringopeptine operon in Pss B728a.

Additional file 4: Arginine auxotrophy. The wild type, two arginine biosynthesis defective Tn5 mutants Pfv 169 and Pfv 270, their respective 
knock-out mutants and one other Tn5 mutant Pfv 102 as a control were streaked onto A: LB agar plate, B: M9 plate with $2 \%$ CAS amino acid, C: M9 plate with $2 \%$ glucose and D: M9 plate with $2 \%$ glucose and $25 \mu \mathrm{g} / \mathrm{ml}$ of arginine- $\mathrm{HCl}$. (+) and (-) indicates growth and no growth respectively.

Additional file 5: List of plasmids used in this study. Additional file 6: List of primers used in this study.

\section{Competing interests}

The authors declare that they have no competing interest.

\section{Author's contributions}

HKP, MH and $\mathrm{W}$ designed the experiments. HKP, MM, IB, VB and GJA performed the experiments. HKP, MH and W drafted the manuscript. All authors read and approved the final manuscript.

\section{Acknowledgements}

HKP was supported from ICGEB doctoral fellowship. We thank Dr. Robert W. Jackson (Univeristy of Reading, UK) for his support and valuable comments throughout.

\section{Author details}

${ }^{1}$ International Centre for Genetic Engineering and Biotechnology, Trieste, Italy. ${ }^{2}$ Department of Crop Protection, Laboratory of Phytopathology, Ghent University, Coupure, Links 653, 9000 Ghent, Belgium. ${ }^{3}$ Graham Centre for Agricultural Innovation, School of Agricultural and Wine Sciences, Charles Sturt University, Wagga Wagga, NSW 2650, Australia.

Received: 6 August 2014 Accepted: 23 October 2014

Published online: 14 November 2014

\section{References}

1. Miyajima K, Tanii A, Akita T: Pseudomonas fuscovaginae sp. nvm. rev. Int J Syst Bacteriol 1983, 33:656-657.

2. Tanii A, Miyajima K, Akita T: The sheath brown rot disease of rice and its causal bacterium Pseudomonas fuscovaginae sp. nov. Ann Phytopathological Soc Japan 1976, 42:540-548.

3. Anzai Y, Kim H, Park JY, Wakabayashi H, Oyaizu H: Phylogenetic affiliation of the pseudomonads based on 16S rRNA sequence. Int J Syst Evol Microbiol 2000, 50(Pt 4):1563-1589.

4. Hofte M, De Vos P: Plant Pathogenic Pseudomoans Species. In Plant-Associated Bacteria. Edited by Gnanamanickam SS. Netherlands: Springer; 2006:507-533.

5. Duveiller E, Snacken F, Maraite H: First detection of Pseudomonas fuscovaginae on maize and sorghum in Burundi. Plant Disease 1989, 73:514-517.

6. Rott $P$, Nottheghem JL, Frossard P: Identification and characterization of Pseudomonas fuscovaginae, the causal agent of bacterial sheath brown rot of rice, from Madagascar and other countries. Plant Disease 1989, 73:133-137.

7. Duveiller E: Bacterial sheath rot of wheat caused by Pseudomonas fuscovaginae in the highlands of Mexico. Plant Disease 1990, 74:932-935.

8. Cottyn B, Cerez MT, Van Outryve MF, Barroga J, Swings J, Mew TW: Bacterial diseases of rice. I. Pathogenic bacteria associated with sheath rot complex and grain discoloration of rice in the Philippines. Plant Disease 1996, 80:429-437.

9. Sharma S, Sthapit BR, Pradhanang PM, Joshi KD, BsbrorcbPfiNp-IRcihaC Bacterial Sheath Brown Rot of Rice caused by Pseudomonas fuscovaginae in Nepal. In "Rice Cultivation in Highland Areas". Edited by Poisson C, Rakotoarisoa J. Montpellier, France: CIRAD-CA; 1997:107-112. Proc of the CIRAD Conference, Antananarivo, Madagascar 29 March-5 April 1996.

10. Malavolta VMA, Almeida IMG, Malavolta JVA: Characterization of Pseudomonas fuscovaginae on rice in Sao Paulo State, Brazil, and reaction of rice cultivars to the bacterium. Summa Phytopathol 1997 23:29-35.

11. Xie GL: First report of sheath brown rot of rice in China and characterization of the causal organism by phenotypic tests and Biolog. Intl Rice Res Notes 2003, 28:50-52.
12. Rostam M, Rahimian H, Gasemi A: Identification of pseudomonas fuscovaginaeas the bacterial sheath brown rot of rice in the North of Iran. Iran J PlantPathol 2005, 41:57-58.

13. Razak A, Zainudin N, Sidige S, Ismail N, Mohamad N, Salleh B: Sheath brown rot disease of rice caused by Pseudomonas Fuscovaginae in the Peninsular Malaysia. J Plant Protect Res 2009, 49(3):244-249.

14. Cother EJ, Stodart B, Noble DH, Reinke R, Van de Ven RJ: Polyphasic identification of Pseudomonas fuscovaginae causing sheath and glume lesions on rice in Australia. Australas Plant Pathol 2009, 38:247-261.

15. Zeigler RS, Alvarez E: Bacterial sheath brown rot of rice by Pseudomonas fuscovaginae in latin America. Plant Disease 1987, 71:592-597.

16. Romantschuk M, Bamford DH: The causal agent of halo blight in bean, Pseudomonas syringae pv. phaseolicola, attaches to stomata via its pili. Microb Pathog 1986, 1(2):139-148.

17. Suoniemi A, Björklöf K, Haahtela K, Romantschuk M: Pili of Pseudomonas syringae pathovar syringae enhance initiation of bacterial epiphytic colonization of bean. Microbiology 1995, 141(2):497-503.

18. Roine E, Raineri DM, Romantschuk M, Wilson M, Nunn DN: Characterization of type IV pilus genes in Pseudomonas syringae pv. tomato DC3000. Mol Plant Microbe Interact 1998, 11(11):1048-1056.

19. Nguyen LC, Taguchi F, Tran QM, Naito K, Yamamoto M, Ohnishi-Kameyama M, Ono H, Yoshida M, Chiku K, Ishii T, Inagaki Y, Toyoda K, Shiraishi T, Ichinose Y: Type IV pilin is glycosylated in Pseudomonas syringae pv. tabaci 6605 and is required for surface motility and virulence. Mol Plant Pathol 2012, 13(7):764-774.

20. Taguchi F, Ichinose $Y$ : Role of type IV pili in virulence of Pseudomonas syringae pv. tabaci 6605: correlation of motility, multidrug resistance, and HR-inducing activity on a nonhost plant. Mol Plant Microbe Interact 2011, 24(9):1001-1011.

21. Laue H, Schenk A, Li H, Lambertsen L, Neu TR, Molin S, Ullrich MS: Contribution of alginate and levan production to biofilm formation by Pseudomonas syringae. Microbiology 2006, 152(Pt 10):2909-2918.

22. Yu J, Penaloza-Vazquez A, Chakrabarty AM, Bender CL: Involvement of the exopolysaccharide alginate in the virulence and epiphytic fitness of Pseudomonas syringae pv. syringae. Mol Microbio/ 1999. 33(4):712-720.

23. Jha G, Rajeshwari R, Sonti RV: Functional interplay between two Xanthomonas oryzae pv, oryzae secretion systems in modulating virulence on rice. Mol Plant Microbe Interact 2007, 20(1):31-40.

24. Collmer A, Badel JL, Charkowski AO, Deng WL, Fouts DE, Ramos AR, Rehm AH, Anderson DM, Schneewind O, van Dijk K, Alfano JR: Pseudomonas syringae Hrp type III secretion system and effector proteins. Proc Natl Acad Sci U S A 2000, 97(16):8770-8777.

25. Bender CL, Alarcon-Chaidez F, Gross DC: Pseudomonas syringae phytotoxins: mode of action, regulation, and biosynthesis by peptide and polyketide synthetases. Microbio/ Mol Biol Rev: MMBR 1999, 63(2):266-292.

26. Bjarnsholt $T$, Jensen PO, Jakobsen TH, Phipps R, Nielsen AK, Rybtke MT, Tolker-Nielsen T, Givskov M, Hoiby N, Ciofu O: Quorum sensing and virulence of Pseudomonas aeruginosa during lung infection of cystic fibrosis patients. PloS one 2010, 5(4):e10115.

27. Brint JM, Ohman DE: Synthesis of multiple exoproducts in Pseudomonas aeruginosa is under the control of RhIR-Rhll, another set of regulators in strain PAO1 with homology to the autoinducer-responsive LuxR-Luxl family. J bacteriol 1995, 177(24):7155-7163.

28. Jones S, Yu B, Bainton NJ, Birdsall M, Bycroft BW, Chhabra SR, Cox AJ, Golby P, Reeves PJ, Stephens S, Winson MK, Salmond GPC, Stewart GSAB, Williams $P$ : The lux autoinducer regulates the production of exoenzyme virulence determinants in Erwinia carotovora and Pseudomonas aeruginosa. The EMBO journal 1993, 12(6):2477-2482.

29. Passador L, Cook JM, Gambello MJ, Rust L, Iglewski BH: Expression of Pseudomonas aeruginosa virulence genes requires cell-to-cell communication. Science 1993, 260(5111):1127-1130.

30. Quinones B, Dulla G, Lindow SE: Quorum sensing regulates exopolysaccharide production, motility, and virulence in Pseudomonas syringae. Mol Plant Microbe Interact 2005, 18(7):682-693.

31. Mattiuzzo M, Bertani I, Ferluga S, Cabrio L, Bigirimana J, Guarnaccia C, Pongor S, Maraite $\mathrm{H}$, Venturi $\mathrm{V}$ : The plant pathogen Pseudomonas fuscovaginae contains two conserved quorum sensing systems involved in virulence and negatively regulated by RsaL and the novel regulator RsaM. Environ Microbiol 2011, 13(1):145-162. 
32. Ballio A, Bossa F, Camoni L, Di Giorgio D, Flamand MC, Maraite $H$, Nitti G, Pucci P, Scaloni A: Structure of fuscopeptins, phytotoxic metabolites of Pseudomonas fuscovaginae. FEBS letters 1996, 381(3):213-216.

33. Flamand MC, Pelsser S, Ewbank E, Maraite H: Production of syringotoxin and other bioactive peptides by Pseudomonas fuscovaginae. Physiol Mol Plant Pathol 1996, 48(4):217-231.

34. Patel HK, da Silva DP, Devescovi G, Maraite H, Paszkiewicz K, Studholme DJ, Venturi V: Draft genome sequence of Pseudomonas fuscovaginae, a broad-host-range pathogen of plants. J bacterio/ 2012, 194(10):2765-2766.

35. Grant SG, Jessee J, Bloom FR, Hanahan D: Differential plasmid rescue from transgenic mouse DNAs into Escherichia coli methylation-restriction mutants. Proc Natl Acad Sci U S A 1990, 87(12):4645-4649.

36. Figurski DH, Helinski DR: Replication of an origin-containing derivative of plasmid RK2 dependent on a plasmid function provided in trans. Proc Natl Acad Sci U S A 1979, 76(4):1648-1652

37. Diorio C, Cai J, Marmor J, Shinder R, DuBow MS: An Escherichia coli chromosomal ars operon homolog is functional in arsenic detoxification and is conserved in gram-negative bacteria. J bacteriol 1995, 177(8):2050-2056.

38. Weerasinghe JP, Dong T, Schertzberg MR, Kirchhof MG, Sun Y, Schellhorn HE: Stationary phase expression of the arginine biosynthetic operon argCBH in Escherichia coli. BMC microbiology 2006, 6:14.

39. Cunin R, Glansdorff N, Pierard A, Stalon V: Biosynthesis and metabolism of arginine in bacteria. Microbiol Rev 1986, 50(3):314-352.

40. Ramon-Maiques S, Marina A, Gil-Ortiz F, Fita I, Rubio V: Structure of acetylglutamate kinase, a key enzyme for arginine biosynthesis and a prototype for the amino acid kinase enzyme family, during catalysis. Structure 2002, 10(3):329-342.

41. Weingart H, Ullrich H, Geider K, Volksch B: The Role of Ethylene Production in Virulence of Pseudomonas syringae pvs. glycinea and phaseolicola. Phytopathology 2001, 91(5):511-518.

42. Bronstein PA, Marrichi M, Cartinhour S, Schneider DJ, DeLisa MP: Identification of a twin-arginine translocation system in Pseudomonas syringae pv. tomato DC3000 and its contribution to pathogenicity and fitness. J bacteriol 2005, 187(24):8450-8461.

43. Caldelari I, Mann S, Crooks C, Palmer T: The Tat pathway of the plant pathogen Pseudomonas syringae is required for optimal virulence. Mol Plant Microbe Interact 2006, 19(2):200-212.

44. Venkatachalam KV, Akita H, Strott CA: Molecular cloning, expression, and characterization of human bifunctional 3'-phosphoadenosine 5'phosphosulfate synthase and its functional domains. J Bioll Chem 1998, 273(30):19311-19320.

45. Alm RA, Bodero AJ, Free PD, Mattick JS: Identification of a novel gene, pilZ, essential for type 4 fimbrial biogenesis in Pseudomonas aeruginosa. J bacteriol 1996, 178(1):46-53.

46. Guzzo CR, Salinas RK, Andrade MO, Farah CS: PILZ protein structure and interactions with PILB and the FIMX EAL domain: implications for control of type IV pilus biogenesis. J Mol Biol 2009, 393(4):848-866.

47. McCarthy Y, Ryan RP, O'Donovan K, He YQ, Jiang BL, Feng JX, Tang JL, Dow JM: The role of PilZ domain proteins in the virulence of Xanthomonas campestris pv. campestris. Mol Plant Pathol 2008, 9(6):819-824.

48. Fouhy Y, Lucey JF, Ryan RP, Dow JM: Cell-cell signaling, cyclic di-GMP turnover and regulation of virulence in Xanthomonas campestris. Res Microbiol 2006, 157(10):899-904

49. Bingle LE, Bailey CM, Pallen MJ: Type VI secretion: a beginner's guide. Curr Opin Microbiol 2008, 11(1):3-8.

50. Bonemann G, Pietrosiuk A, Mogk A: Tubules and donuts: a type VI secretion story. Mol Microbiol 2010, 76(4):815-821.

51. Cascales E: The type VI secretion toolkit. EMBO reports 2008, 9(8):735-741.

52. Leiman PG, Basler M, Ramagopal UA, Bonanno JB, Sauder JM, Pukatzki S, Burley SK, Almo SC, Mekalanos JJ: Type VI secretion apparatus and phage tail-associated protein complexes share a common evolutionary origin. Proc Natl Acad Sci U S A 2009, 106(11):4154-4159.

53. Records AR: The type VI secretion system: a multipurpose delivery system with a phage-like machinery. Mol Plant-microbe Interact: MPMI 2011 24(7):751-757

54. Pell LG, Kanelis V, Donaldson LW, Lynne Howell P, Davidson AR: The phage $\lambda$ major tail protein structure reveals a common evolution for long-tailed phages and the type VI bacterial secretion system. Proc Natl Acad Sci 2009, 106(11):4160-4165
55. Wu HY, Chung PC, Shih HW, Wen SR, Lai EM: Secretome analysis uncovers an Hcp-family protein secreted via a type VI secretion system in Agrobacterium tumefaciens. J bacterio/ 2008, 190(8):2841-2850.

56. Wichmann G, Sun J, Dementhon K, Glass NL, Lindow SE: A novel gene, phcA from Pseudomonas syringae induces programmed cell death in the filamentous fungus Neurospora crassa. Mol Microbiol 2008, 68(3):672-689.

57. Liu H, Coulthurst SJ, Pritchard L, Hedley PE, Ravensdale M, Humphris S, Burr T, Takle G, Brurberg MB, Birch PR, Salmond GPC, Toth IK: Quorum sensing coordinates brute force and stealth modes of infection in the plant pathogen Pectobacterium atrosepticum. PLoS Pathog 2008, 4(6):e1000093.

58. Scholz-Schroeder BK, Soule JD, Gross DC: The sypA, sypS, and sypC synthetase genes encode twenty-two modules involved in the nonribosomal peptide synthesis of syringopeptin by Pseudomonas syringae pv. syringae B301D. Mol Plant-microbe Interact: MPMI 2003, 16(4):271-280

59. Feil H, Feil WS, Chain P, Larimer F, DiBartolo G, Copeland A, Lykidis A, Trong S, Nolan M, Goltsman E, Thiel J, Malfatti S, Loper JE, Lapidus A, Detter JC, Land M, Richardson PM, Kyrpides NC, Ivanova N, Lindow SE: Comparison of the complete genome sequences of Pseudomonas syringae pv. syringae B728a and pv. tomato DC3000. Proc Natl Acad Sci U S A 2005, 102(31):11064-11069.

60. Scholz-Schroeder BK, Soule JD, Lu SE, Grgurina I, Gross DC: A physical map of the syringomycin and syringopeptin gene clusters localized to an approximately 145-kb DNA region of Pseudomonas syringae pv. syringae strain B301D. Mol Plant-microbe Interact: MPMI 2001, 14(12):1426-1435.

61. Vallet-Gely I, Novikov A, Augusto L, Liehl P, Bolbach G, Pechy-Tarr M, Cosson $P$, Keel C, Caroff M, Lemaitre B: Association of hemolytic activity of Pseudomonas entomophila, a versatile soil bacterium, with cyclic lipopeptide production. App/ Environ Microbio/ 2010, 76(3):910-921.

62. Scholz-Schroeder BK, Hutchison ML, Grgurina I, Gross DC: The contribution of syringopeptin and syringomycin to virulence of Pseudomonas syringae pv. syringae strain B301D on the basis of sypA and syrB1 biosynthesis mutant analysis. Mol Plant-microbe Interact: MPMI 2001, 14(3):336-348

63. Batoko H, De Kerchove D'Exaerde A, Kinet JM, Bouharmont J, Gage RA, Maraite $\mathrm{H}$, Boutry M: Modulation of plant plasma membrane H+-ATPase by phytotoxic lipodepsipeptides produced by the plant pathogen Pseudomonas fuscovaginae. Biochim Biophys Acta 1998, 1372(2):216-226.

64. Menestrina G, Dalla Serra M, Comai M, Coraiola M, Viero G, Werner S, Colin DA, Monteil $H$, Prevost $G$ : Ion channels and bacterial infection: the case of beta-barrel pore-forming protein toxins of Staphylococcus aureus. FEBS letters 2003, 552(1):54-60

65. Xie G, Cui Z, Tao Z, Qiu H, Liu H, Ibrahim M, Zhu B, Jin G, Sun G, Almoneafy A, Li B: Genome sequence of the rice pathogen Pseudomonas fuscovaginae CB98818. J Bacteriol 2012, 194(19):5479-5480.

66. Sambrook JFE, Maniatis T: Molecular Cloning: A Laboratory Manual. 2nd edition. Harbor, N.Y: Press CSHL. Cold Spring; 1989.

67. Birnboim HC: A rapid alkaline extraction method for the isolation of plasmid DNA. Methods Enzymol 1983, 100:243-255.

68. Better M, Lewis B, Corbin D, Ditta G, Helinski DR: Structural relationships among Rhizobium meliloti symbiotic promoters. Cell 1983, 35(2 Pt 1):479-485

69. O'Toole GA, Kolter R: Initiation of biofilm formation in Pseudomonas fluorescens WCS365 proceeds via multiple, convergent signalling pathways: a genetic analysis. Mol Microbiol 1998, 28(3):449-461.

70. Alexeyev MF: The pKNOCK series of broad-host-range mobilizable suicide vectors for gene knockout and targeted DNA insertion into the chromosome of gram-negative bacteria. BioTechniques 1999, 26(5):824.-826, 828

71. Staskawicz B, Dahlbeck D, Keen N, Napoli C: Molecular characterization of cloned avirulence genes from race 0 and race 1 of Pseudomonas syringae pv. glycinea. J Bacterio/ 1987, 169(12):5789-5794.

doi:10.1186/s12866-014-0274-7

Cite this article as: Patel et al:: Identification of virulence associated loci in the emerging broad host range plant pathogen Pseudomonas fuscovaginae. BMC Microbiology 2014 14:274 